Bangladesh J. Bot. 41(1): 49-54, 2012 (June)

\title{
MORPHOLOGICAL AND MOLECULAR IDENTIFICATION OF FUSARIUM OXYSPORUM SCH. ISOLATED FROM GUAVA WILT IN BANGLADESH
}

\author{
M Zakir Hussain ${ }^{*}$, MA Rahman ${ }^{2}$, Mohammad Nurul Islam, MA Latif ${ }^{3}$ \\ AND MA BASHAR \\ Department of Botany, University of Dhaka, Dhaka-1000, Bangladesh
}

Key words: Molecular identification, Guava wilt, Fusarium oxysporum, PCR

\begin{abstract}
Wilt of guava plants (Psidium guajava L.) is a serious disease in Bangladesh. Sixteen isolates of Fusarium oxysporum Sch. were collected from the root and stem fragments of guava plants growing in six districts of Bangladesh. Species identity was based on the colony character, nature of conidiogenous cell, morphology of microconidia, macroconidia and chlamydospores. Eleven isolates were confirmed as F. oxysporum through polymerase chain reaction (PCR) using species specific primers designed from the conserved regions of $18 \mathrm{~S}$ rRNA gene.
\end{abstract}

\section{Introduction}

In Bangladesh guava is one of the cheapest fruits and good source of vitamins. During 2005 2006 , total production of guava was 145685 MT (Anon. 2008). Ten diseases of guava were reported by different workers mentioning wilt as a major pernicious disease and reported $10-25 \%$ loss (Talukdar 1974). Meah and Al-Mamun (1991) reported 18 - 36\% guava wilt from five selected districts of Bangladesh.

Wilt disease which is a sudden, catastrophic killer, known as the "Cancer of guava production". July-October is suitable for wilt and per cent death is quicker during this time (Meah et al. 1995). At the seedling stage, infected plants may wilt and die soon. In older plants, vein clearing and leaf epinasty are often followed by stunting, yellowing of the lower leaves and then the tree is defoliated. When decline is rapid, leaves tend to shrivel and assume a fire scorched appearance. Browning of the vascular tissue is a strong evidence of Fusarium wilt. Das and Rai (1947) indicated the association of Fusarium sp. with the wilt disease of guava. Prasad et al. (1952) identified Fusarium oxysporum as wilt causing organism of guava and proposed the name Fusarium oxysporum Sch. f. sp. psidii Prasad, Mehta and Lal. Edward (1960a), Pandey and Dwivedi (1985), Meah and Al-Mamun (1991) and Hamiduzzaman et al. (1997) agreed upon the identification of wilt pathogen of guava as proposed by Prasad et al. (1952).

In the present investigation, an attempt was made to characterize the wilt pathogen/s of guava occurring in Bangladesh on the basis of morphological characters and PCR analysis.

\section{Materials and Methods}

The fresh root and stem fragments from guava trees showing typical wilt symptoms were collected from Barisal, Brahmanbaria, Chittagong, Faridpur, Gazipur, Khagrachari, Pirojpur and Rangpur districts of Bangladesh. Collected samples were cut into $10-15 \mathrm{~cm}$ lengths washed in running tap water followed by sterile distilled water and then splited lengthwise and cut into thin small pieces $(\leq 1 \mathrm{~cm})$. The cut pieces were surface sterilized with $0.1 \% \mathrm{HgCl}_{2}$ solution. The

*Author for correspondence: <zakir7511@yahoo.com>. ${ }^{1}$ Present address: Program Officer, Higher Education Quality Enhancement Project, UGC. ${ }^{2}$ Bangladesh Agricultural Research Institute, Gazipur, Bangladesh. ${ }^{3}$ Bangladesh Rice Research Institute, Gazipur, Bangladesh. 
surface sterilized inocula were plated on half-strength PDA medium with three inocula per Petri plate $\left(9 \mathrm{~cm}\right.$ in dia.) (Burgess et al. 1975). Inoculated Petri plates were incubated at $26 \pm 1^{\circ} \mathrm{C}$ for five days. Pure culture was obtained through culturing macroconidia in water agar (Burgess et al. 1994).

Purified isolates were kept at $4^{\circ} \mathrm{C}$ by culturing them on PDA slants and for long time preservation cultured on water soaked wheat bran medium. Well grown cultures in wheat bran were air dried, wrapped with brown paper and kept at $2-4^{\circ} \mathrm{C}$ for further use.

Morphological studies of the isolates were carried out by culturing them on PDA plates and wheat bran at $26 \pm 1^{\circ} \mathrm{C}$ for five days. Colony colour, radial growth and sporulation were recorded for all the isolates. Morphological characters were studied following Burgess et al. (1994) and Aneja (2003). Colony diameters of the isolates were measured after three days of incubation at 26 $\pm 1^{\circ} \mathrm{C}$. The colony morphology was recorded on the 12 th day of incubation at 25 and $20^{\circ} \mathrm{C}$ during day and night, respectively.

Fusarium oxysporum specific primers were designed using Primer 3 software (Steve and Skaletsky 2000) from the conserved regions of 18S rRNA gene of the Accession No. GQ131884.1. The selected forward primer (GCCAGAGGACCCCTAAACTC) and reverse primer (CATTTTG CTGCGTTCTTCAT) were expected to produce a PCR product with a band size of $118 \mathrm{bp}$. The primers were synthesized and supplied by BIONEER Inc., USA.

Genomic DNA of 16 isolates was extracted from mycelia grown in liquid medium. A modified DNA extraction method of Ali (2002) was followed in the present investigation and purified DNA samples were kept in $-20^{\circ} \mathrm{C}$ freezer for further analysis.

The PCR was initiated by a initial denaturation step at $94^{\circ} \mathrm{C}$ for 5 minutes following 35 cycles of 94,54 and $72^{\circ} \mathrm{C}$ each for $30 \mathrm{sec}$, with a final extension step of $5 \mathrm{~min}$ at $72^{\circ} \mathrm{C}$ and ended with $4^{\circ} \mathrm{C}$. The PCR was carried out in an Eppendorf Mastercycler with 25 micro tubes capacity. PCR amplified products were stored in $-20^{\circ} \mathrm{C}$ freezer for analysis by resolving in $2 \%$ agarose gel. The gel was prepared with ethidium bromide (final concentration $0.5 \mu \mathrm{g} / \mathrm{ml}$ ) and after resolving the PCR amplified DNA the gel was viewed in a gel documentation system (microDoc, Cleaver Scientific Ltd.) to take picture.

\section{Results and Discussion}

During the present investigation the wilt causing fungi has been isolated from roots and stems of recently wilted guava plants. The causal organism of guava wilt was identified as Fusarium oxysporum. This identification is in agreement with the findings of other earlier workers (Prasad et al. 1952, Edward 1960a, Akanda and Mian 1981, Pandey and Dwivedi 1985, Dwivedi and Dwivedi 1994, Dolly et al. 2006 and Gupta et al. 2010).

Root and stem inocula produced 81.11 and $62.22 \%$ colonies of $F$. oxysporum on half-strength PDA medium. Finally, a total of 16 isolates of $F$. oxysporum were purified. The colony diameter of the pathogen ranged from $3.2-4.5 \mathrm{~cm}$ on the fourth day of inoculation in PDA medium (Table 1). The mycelia of the isolates were delicate, white to creamy and tinge pink or purple tinge, sparse to abundant than floccose, margins slightly lobed or smooth on PDA (Fig.1a - d). In water soaked wheat bran isolates produced pale to dark violet or dark magenta pigment.

Numerous micro- and macroconidia were observed in case of all the 16 isolates on PDA and water soaked wheat bran (Fig. 2 a, b). Microconidia formed singly, oval to reniform and without any septation. Conidiogenous cells bearing micro- and macroconidia were monophialides type. The size of microconidia ranged from $7.50-16.25$ and $2.50-4.50 \mu \mathrm{m}$. Macroconidia were falcate to almost straight, usually 3 -septed, rarely four to 5 -septed, thin walled, both ends almost pointed, notched basal cell, apical cell short and in some cases slightly curved. Macroconidia were 
produced in sporodochia as well as on normal hyphae and slimy conidial masses were also observed on water soaked wheat bran. The size of the macroconidia ranged from $20.27-40.50$ and $5.00-6.75 \mu \mathrm{m}$ (Table 1).

Table 1. Macroconidial measurement and colony diameter of 11 isolates of Fusarium oxysporum on water soaked wheat bran and PDA medium.

\begin{tabular}{|c|c|c|c|c|}
\hline $\begin{array}{l}\text { Source of } \\
\text { isolates }\end{array}$ & $\begin{array}{l}\text { Isolate } \\
\text { number }\end{array}$ & $\begin{array}{l}\text { Macroconidia (Length/ } \\
\text { breadth } \mu \mathrm{m}) *\end{array}$ & $\begin{array}{l}\text { Colony diameter } \\
\left(4^{\text {th }} \text { day }\right) \mathrm{cm}\end{array}$ & Chlamydospores \\
\hline $\begin{array}{l}\text { Kazi peyara } \\
\text { BARI, Gazipur }\end{array}$ & Fop 1 & $25.28-31.12 / 5.00$ & 3.2 & + \\
\hline $\begin{array}{l}\text { Kazi peyara } \\
\text { BARI, Gazipur }\end{array}$ & Fop 2 & $28.75-35.51 / 5.00$ & 3.5 & + \\
\hline $\begin{array}{l}\text { Mukundapuri } \\
\text { B. Baria }\end{array}$ & Fop 4 & $27.75-35.49 / 6.00$ & 3.8 & + \\
\hline $\begin{array}{l}\text { BARI peyara-2 } \\
\text { Khagrachari }\end{array}$ & Fop 5 & $21.49-29.23 / 5.00$ & 3.8 & + \\
\hline $\begin{array}{l}\text { Kanchannagar } \\
\text { Chittagong }\end{array}$ & Fop 6 & $29.73-39.43 / 6.75$ & 4.2 & + \\
\hline $\begin{array}{l}\text { Kazi peyara } \\
\text { Bhora, Gazipur }\end{array}$ & Fop 7 & $20.27-25.57 / 5.00$ & 4.5 & + \\
\hline $\begin{array}{l}\text { Kazi peyara } \\
\text { Faridpur }\end{array}$ & Fop 9 & $26.17-38.27 / 6.25$ & 3.8 & + \\
\hline $\begin{array}{l}\text { Kazi peyara } \\
\text { Rangpur }\end{array}$ & Fop 11 & $28.50-40.50 / 6.25$ & 4.0 & + \\
\hline $\begin{array}{l}\text { BARI-2 } \\
\text { Khagrachari }\end{array}$ & Fop 13 & $24.37-30.67 / 6.00$ & 3.8 & + \\
\hline $\begin{array}{l}\text { Kazi peyara } \\
\text { Faridpur }\end{array}$ & Fop 14 & $26.76-34.24 / 6.25$ & 3.9 & + \\
\hline $\begin{array}{l}\text { Kazi peyara } \\
\text { BARI, Gazipur }\end{array}$ & Fop 16 & $27.50-32.50 / 5.00$ & 4.0 & + \\
\hline
\end{tabular}

*Dimensions obtained from standard deviation of ten readings in each case using the formula $\sqrt{ }(\mathrm{X}-\mathrm{X})^{2} / \mathrm{n}-1$.

Out of 16 isolates 11 produced chlamydospores on culture media. Chlamydospores were thick walled, terminal or intercalary, globose, smooth or wrinkled, generally single celled (6.25 - 9.25 $\mu \mathrm{m})$ produced in hyphae and conidia. Chlamydospores were also found in two celled or in cluster $(10.0$ - 30.0/7.5 $\mu \mathrm{m})$ and in chain form $(17.5-30.0 / 7.5 \mu \mathrm{m})$.

The above mentioned morphological characters were considered as secondary criteria for the identification of F. oxysporum (Burgess et al. 1994). Booth (1977) considered the conidiogenous cell bearing microconidia as a primary taxonomic criterion and growth rate as a secondary criterion for the identification of $F$. oxysporum. The shape of macroconidia produced in sporodochia is one of the primary defining characteristics of Fusarium spp. and are preferred in identification purpose. Edward (1960b) reported the wilt causing pathogen F. oxysporum f. sp. psidii exists in a variety of clonal forms which differ in pathogenicity, morphological and cultural characters. 

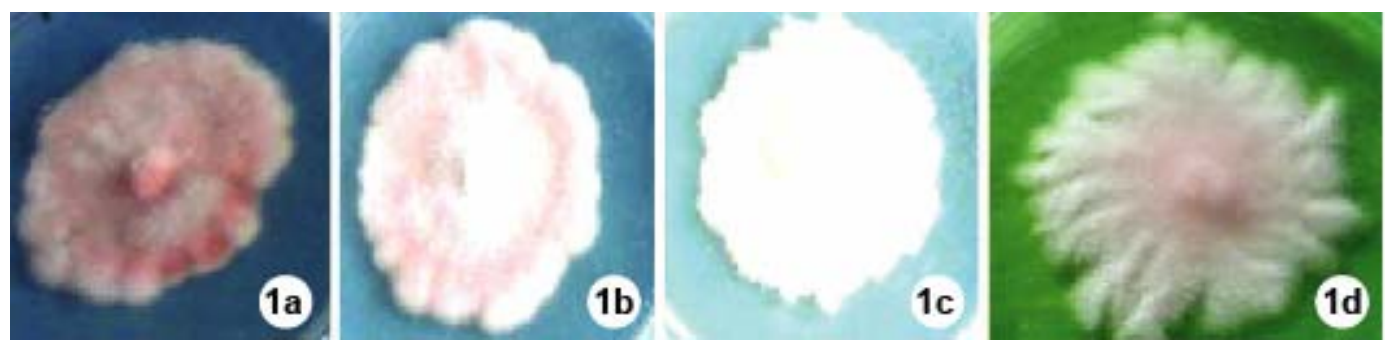

Fig. 1a - d. Colonial morphology of four virulent isolates of Fusarium oxysporum $\mathrm{f}$. sp. psidii. Isolates a, b and d produced pink colony, c produced creamy white colony on PDA.
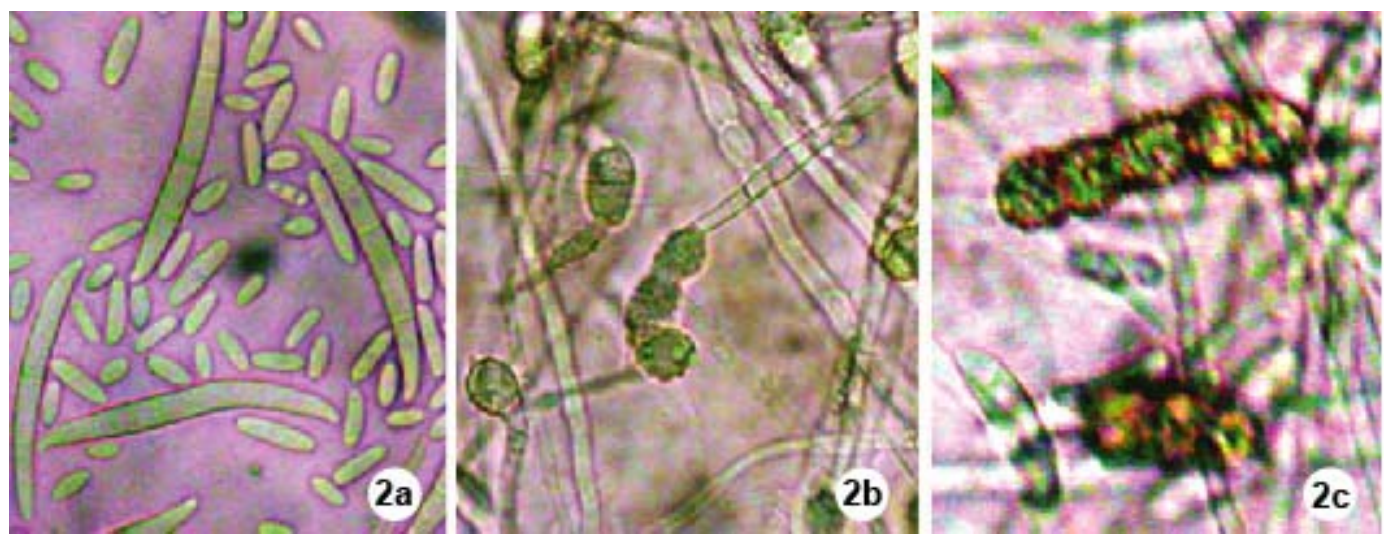

Fig. 2a-c: Fusarium oxysporum f. sp. psidii. a, macro- and microconidia; b, terminal and intercalary chlamydospores; c, chlamydospores in chain.

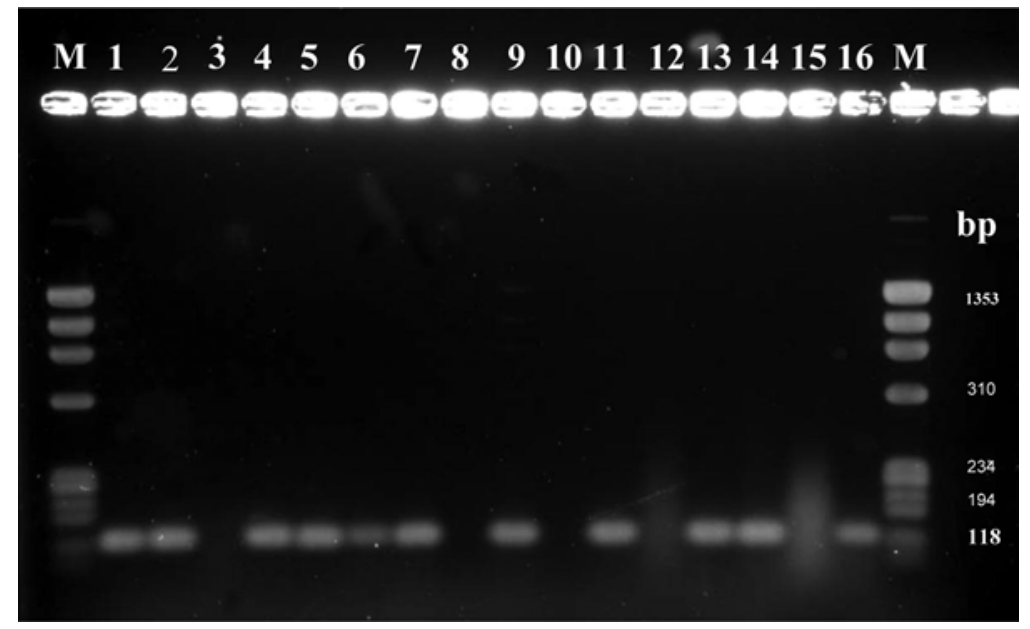

Fig. 3. PCR result of 16 isolates of Fusarium oxysporum by using specific primers. Lanes M are phi X 174 DNA/Hae III markers. Lanes 1 - 16 are DNA samples of Fusarium oxysporum isolates form wilted guava plants. 
In the present investigation, sometimes it was difficult to distinguish $F$. oxysporum from other species of Fusarium based on the morphological features. This is in agreement with the findings of Gupta et al. (2010). Therefore, molecular characterization of the F. oxysporum was conducted for proper identification using PCR analysis. The genomic DNA isolated from morphologically identified $16 \mathrm{~F}$. oxysporum isolates was subjected to PCR amplification. It was expected to amplify a 118 bp size fragment of the F. oxysporum 18S rRNA gene in the PCR amplification reaction using gene specific primers designed from the conserved regions. After agarose gel electrophoresis of the PCR amplified DNA it was observed that the selected primer pair exclusively amplified the expected $18 \mathrm{~S}$ rDNA band of $118 \mathrm{bp}$ size in 11 morphologically identified isolates of $F$. oxysporum. On the other hand, no amplification was observed in case of the isolates 3, 8, 10, 12 and 15 and was not considered as F. oxysporum (Fig. 3).

Development of specific primers for F. moniliformae was also reported by other workers (Murillo et al. 1998, Moller et al. 1999). Hence, the results described here proved that the primer pair allowed a fast, reliable and specific identification of Fusarium oxysporum isolates and could be suitable for early diagnosis of Fusarium wilt of guava by plant pathologists.

\section{Acknowledgements}

The research is a part of the Ph.D. work by the first author (MZH). He is grateful to the University Grants Commission of Bangladesh for granting a fellowship and financial support to carry out the research and BARI and BRRI for providing laboratory and experimental supports.

\section{References}

Akanda SI and MAW Mian 1981. Wilting of guava (Psidium guajava L.) M. Sc.(Ag.) Thesis, Dept. Plant Pathol., BAU, Mymensingh.

Ali MA 2002. Biological variation and chemical control of Rhizoctonia solani causing sheath blight disease of rice in Bangladesh. Ph.D. Thesis, Imperial College of Science, Technology and Medicine. Silwood park, Ascot Berkshire, U.K.

Aneja KR 2003. Micrometry. In: Experiments in Microbiology, Plant Pathology and Biotechnology. Section IV. 4th ed., New Age Int. Publ., 61-65 pp.

Anonymous 2008. Year Book of Agricultural Statistics of Bangladesh. Bangladesh Bureau of Statistics. 19th ed. July, 2008. Ministry of Planning. 104 p.

Booth C 1977. Fusarium - Laboratory guide to the identification of the major species. $1^{\text {st }}$ Edn. Commonwelth Mycological Institute, Kew, Surrey, England. 58 pp.

Burgess LW, AH Wearing and TA Toussoun 1975. Surveys of the Fusaria associated with crown rot of wheat in eastern Australia. Aust. J. Agril. Res. 26: 791-799.

Burgess LW, BA Summerell, S Bullock, KP Gott and D Backhouse1994. Laboratory Manual for Fusarium Research. Fusarium Research Laboratory, Department of Crop Sciences, University of Sydney and Royal Botanic Gardens, Sydney. 133 p.

Das Gupta SN and JN Rai 1947. Wilt disease of guava (Psidium guyava L.) Current Science 16(8): 256-258.

Dolly J, P Gupta and V Gupta 2006. Etiology and management of guava wilt disease in Allahabad and Kaushambi districts of Utter Pradesh, India. J. Mycol. Plant Pathol. 36(3): 356-372.

Dwivedi SK and RS Dwivedi 1994. Population dynamics of guava (Psidium guajava L.) wilt pathogens in pesticides treated soil. Int. J. Tropi. Plant Dis. 12(2): 187-195.

Edward JC 1960a. Wilt disease of guava. The Allahabad Farmer. 34(5): 289-293.

Edward JC 1960b. Variation in the guava wilt pathogen, Fusarium oxysporum f. sp. psidii. Indian Phytopathol. 13: 30-36.

Gupta VK, AK Misra, RK Gaur, PK Jain, D Gaur and S Sharma 2010. Current status of Fusarium wilts disease of guava (Psidium guajava L.) in India. Biotechnology. 9: 176-195. 
Hamiduzzaman MM, MB Meah and MU Ahmad 1997. Effect of Fusarium oxysporum and nematode interaction on guava wilt. Bangladesh J. Plant Pathol. 13(1 \& 2): 9-11.

Meah MB and S Al-Mamun 1991. Investigation of wilting of guava (Psidium guajava L ). Proc. BAU Res. Prog. 5: 17-24.

Meah MB, MD Hossain and MAU Doula 1995. Guava wilt control: an integrated approach. BAU Res. Prog. 9: $74-78$.

Moller E, M Chelkowski and HH Geiger 1999. Species specific PCR assays for the fungal pathogen Fusarium moniliformae and F. subglutinans and their application to diagnose maize ear rot disease. J. Phytopathol. 147: 497-508.

Murillo EO, E Cavallarin and BS Segundo 1998. The development of a rapid PCR assay for detection of Fusarium moniliformae. European J. Plant Pathol. 104: 301-311.

Pandey RR and RS Dwivedi 1985. Fusarium oxysporum f. sp. psidii as a pathogen causing wilt of guava (Psidium guajava) in Varanasi district, India. Phytopathologische Zeitschrift. 114(3): 243-248.

Prasad N, PR Mehta and SB Lal 1952. Fusarium wilt of guava (Psidium guava L.) in Uttar Pradesh, India. Nature 169(2):753

Steve R and HJ Skaletsky 2000. Primer 3 on the www for general users and for biologist programmers. In: Bioformatics methods and protocols: Methods in Molecular Biology. S. Krawetz and S. Misener (Eds), Humana Press, Totowa, NJ. 365-386. http://fokker.wi.mit.edu/primer3/.

Talukdar MJ 1974. Plant diseases in Bangladesh. Bangladesh J. Agric. Res. 1(2): 61-86.

(Manuscript received on 23 January, 2012; revised on 27 May, 2012) 